\title{
ALASAN NASABAH NON MUSLIM MEMILIH PEMBIAYAAN MURABAHAH DI BANK SYARIAH (Studi Kasus Nasabah Di BNI Syariah KC. Rungkut Surabaya)1)
}

\author{
Amaliah Al Azmi \\ Mahasiswa Program Studi S1 Ekonomi Islam-Fakultas Ekonomi dan Bisnis-Universitas Airlangga \\ Email: amaliah.azmi@gmail.com \\ R. Moh. Qudsi Fauzy \\ Departemen Ekonomi Syariah-Fakultas Ekonomi dan Bisnis-Universitas Airlangga \\ Email : qudsifauzy1@gmail.com
}

\begin{abstract}
:
This research aims to find the reason of non muslim customers chose murabahah as their funding at BNI Syariah and to find the benefit after they got those funding. This research was conducted at BNI Syariah Branch Office Rungkut Surabaya, involving of 6 non muslim customers as prime respondents and 3 employees of BNI Syariah as second respondent. Data were collected by interviewing the respondents and then the answers compared with the data from marketing or Account Officer as source triangulation. Purposive sampling technique was chosen because there were some criteria to be respondent in this research, that are: the customer should be non muslim and using murabahah. The result of this study showed that there were 3 reason of non muslim customers to choose murabahah as their choice, the first reason was the simplicity of scheme, second reason was the promotion, and the third reason was profit.
\end{abstract}

Keywords : Non Muslim, Islamic Bank, Murabahah

\section{PENDAHULUAN}

Kondisi dunia perbankan di Indonesia telah mengalami banyak perubahan dari waktu ke waktu. Bukan hanya bank konvensional, bank syariah juga mengalami perkembangan yang disignifikan di Indonesia. Keberadaan bank syariah di Indonesia dikukuhkan dalam undang-undang yang menyebutkan bahwa dalam perbankan Indonesia terdapat dua sistem yakni konvensional dan syariah. Hal ini menunjukkan bahwa pengembangan sistem syariah di Indonesia juga merupakan suatu kewajiban karena telah diatur dalam undang-undang.

Lahirnya perbankan syariah di Indonesia dengan beroperasinya Bank Muamalat pada tahun 1992 M yang mempunyai bentuk operasionalisasi jauh berbeda dengan perbankan konvensional diharapkan akan memenuhi kebutuhan yang sangat urgent bagi umat Islam di Indonesia dalam menggunakan jasa perbankan secara syariah.

Salah satu bank syariah terkemuka di Indonesia saat ini adalah BNI Syariah. BNI Syariah didirikan pada tanggal 19 Juni 2010 sebagai Bank Umum Syariah (BUS), $\mathrm{BNI}$ Syariah telah beroperasi selama kurang lebih empat tahun dalam mengabdi kepada negeri. Selama tiga tahun bank milik anak perusahaan BUMN $\mathrm{BNI}$ tersebut, telah memantapkan diri sebagai salah satu bank syariah terkemuka di Indonesia. Meski tergolong muda perkembangan BNI Syariah cukup

1) Jurnal ini merupakan skripsi dari Amaliah Al Azmi, NIM : 041014002. 
menjadikan perhitungan bagi perbankan nasional di tanah air. Dalam perkembangan per 31 Mei 2013 BNI Syariah mampu menyalurkan pembiayaan sebesar $\operatorname{Rp} 9,105$ triliun diberbagai sektor usaha dan sekaligus mampu menghimpun Dana Pihak Ketika (DPK) sebesar Rp 10,875 triliun. Selain itu pula BNI Syariah memiliki keterpihakan sangat besar dalam penyaluran pembiayaan kepada pelaku usaha mikro dimana hingga saat ini sudah Rp 466, 190 milyar pembiayaan yang disalurkan.

Adapun mengenai larangan riba yang merupakan ciri dari sistem perbankan syariah, ternyata memiliki akar yang kuat pada ajaran-ajaran non Muslim. Menurut kalangan Kristen, riba merupakan tindakan kriminal, demikian juga pada acara Hindu dan Budha. Penetrasi terhadap segmen pasar ini diperkirakan akan lebih mudah bila mengingat bahwa ajaran Hindu, Budha dan Kristen pun terdapat ajaran larangan pemungutan riba.

Fenomena menarik ketika sebagian masyarakat Muslim masih memperdebatkan sistem perbankan Syariah (tanpa bunga), justru pada Bank BNI Syariah, kalangan non Muslim mulai melirik dan menikmati produk bank tersebut terutama pada produk penyaluran dana murabahah. Sebanyak $\pm 5 \%$ dari 132 nasabah Bank BNI Syariah Kc. Rungkut adalah orang-orang Kristen yang semuanya mengambil produk murabahah. Kenyataan ini patut dihargai karena di bank tersebut merupakan kantor cabang yang hanya melayani produk penyaluran dana murabahah di sektor mikro saja, berbeda dengan di reguler yang terdapat banyak jenis produk dan juga tidaklah mudah menarik nasabah kalangan non Muslim yang berjiwa bisnis dan mempunyai akar yang kuat pada sistem kapitalis.

Melihat kenyataan tersebut, sangat menarik jika mengetahui alasan atau motivasi nasabah non muslim menggunakan produk-produk dari bank syariah. Oleh karena itu peneliti memutuskan untuk melakukan penelitian tentang "Alasan Nasabah Non Muslim Memilih Pembiayaan Murabahah di Bank Syariah."

\section{LANDASAN TEORI DAN PENGEMBANGAN PROPOSISI}

\section{Ekonomi Islam}

Ekonomi Islam menurut Ryandono (2008:58) adalah ilmu yang mempelajari perilaku manusia dalam usahanya mengatasi adanya gap (kesenjangan) dan permasalahan antara keinginan manusia yang tidak terbatas dengan sumber daya (resources) yang tersedia untuk memenuhi keinginan tersebut bersifat langka (scarcity), sehingga pemenuhan kenginan itu bersifat alternative dan prioritas (apabila satu keinginan dipenuhi lebih dulu maka pemenuhan keinginan yang lain tidak dapat dipenuhi atau harus ditunda), dalam perilakunya tersebut berdasarkan pada ajaran-ajaran (syariah) Islam secara menyelruh (kaffah) dan semuanya dalam rangka beribadah kepada Allah SWT serta 
demi kemaslahatan dan kebahagiaan maupun kesejahteraan lahir batin di dunia sampai akhirat kelak.

\section{Lembaga keuangan}

Wiroso (2009:15) menjelaskan lembaga keuangan adalah badan usaha yang kekayaannya terutama dalam bentuk aset keuangan atau tagihan (claims) dibandingkan dengan aset non finansial atau aset riil. Lembaga keuangan di Indonesia dibagi menjadi Lembaga Keuangan Bank dan Lembaga Keuangan Bukan Bank.

\section{Definisi Bank Syariah}

Undang-undang No. 21 tahun 2008 tentang Bank Syariah pasal 1 mendefinisikan Bank Syariah adalah segala sesuatu yang menyangkut tentang bank syariah dan Unit Usaha Syariah, mencakup kelembagaan, kegiatan usaha, serta cara dan proses dalam melakukan kegiatan usahanya. Kemudian pada ayat 7, Bank Syariah adalah bank yang menjalankan kegiatan usahanya berdasarkan prinsip syariah dan menurut jenisnya terdiri atas Bank Umum Syariah dan Bank Pembiayaan Rakyat Syariah. Pada ayat 12, dijelaskan prinsip syariah adalah prinsip hukum Islam dalam kegiatan perbankan berdasarkan fatwa yang dikeluarkan oleh lembaga yang memiliki kewenangan dalam penetapan fatwa dibidang syariah.

\section{Pengertian Murabahah}

Menurut Fatwa Dewan Syariah Nasional-Majelis Ulama Indonesia (DSNMUI) Nomor 04/DSNMUI/IV/2000 tentang murabahah. Pembiayaan murabahah adalah akad pembiayaan suatu barang dengan menegaskan harga belinya kepada pembeli dan pembeli membayarnya dengan harga yang lebih sebagai keuntungan yang disepakati.

\section{Rukun dan Syarat Murabahah}

Murabahah memiliki rukun-rukun dan syarat-syarat yang harus dipenuhi dalam pelaksanaannya. Wiroso (2009:162) memberikan penjelasan mengenai rukun murabahah yang terdiri dari :

1. Ba'i adalah penjual (pihakyang memiliki barang)

2. Mustari adalah pembeli (oihak yang akan membeli barang)

3. Mabi' adalah barang yang diperjualbelikan

4. Ijab Qabul adalah pernyataan serah terima

Antonio (2001:102) memberikan penjelasan mengenai syarat-syarat yang harus dipenuhi dalam murabahah, yaitu:

1. Penjual memberi tahu biaya barang kepada nasabah

2. Kontrak pertama harus sah sesuai dengan rukun yang ditetapkan

3. Kontrak harus bebas dari riba

4. Penjual harus menjelaskan kepada pembeli bila terjadi cacat atas barang sesudah pembelian

5. Penjual harus menyampaikan semua hal yang berkaitan dengan pembelian, jika pembelian dilakukan secara utang.

\section{Risiko Pembiayaan Murabahah}

Pada pembiayaan murabahah risiko bisa terjadi yang berakibat pada bank, diantara kemungkinan risiko yang harus 


diantisipasi dalam pembiayaan
murabahah antara lain (Antonio,
2001:107) :
a) Default atau kelalaian, nasabah
sengaja tidak membayar angsuran
b) Fluktuasi harga kompratif. Ini terjadi
bila harga suatu barang di pasar
naik setelah bank membelikannya
untuk nasabah. Bank tidak bisa
mengubah harga jual beli
tersebut.
c) Penolakan nasabah, barang yang
dikirim bisa saja ditolak oleh
nasabah karena berbagai sebab
antara lain rusak dalam
perjalanan.

Dijual, karena pembiayaan murabahah bersifat jual beli dengan utang, maka ketika kontrak ditandatangani, barang itu menjadi milik nasabah.

\section{Keunggulan dan Kelemahan Murabahah}

Terdapat beberapa perbedaan utama antara jual beli murabahah dengan pembiayaan konsumen yang membuat pembiayaan murabahah lebih unggul, yaitu:

1) Harga jual pembiayaan konsumen biasanya memakai tingkat bunga yang tergantung situasi pasar, sedangkan margin/tingkat keuntungan murabahah (bila sudah terjadi ijab qabul) bersifat tetap, sehingga harga jual tidak boleh berubah. Keunggulan dari sebuah produk jual beli murabahah adalah memberikan kepastian dan kenyamanan kepada nasabah terhadap angsuran pembiayaan.

2) Akad murabahah adalah akad jual beli, sehingga diwajibkan adanya suatu barang yang diperjualbelikan. Barang yang diperjualbelikan tersebut berupa harta yang jelas harganya, seperti mobil atau motor. Sedangkan akad pembiayaan konsumen adalah akad pinjam meminjam. Dalam hal ini belum tentu ada barangnya.

3) Dalam hal utang nasabah. Dalam jual beli murabahah, utang nasabah adalah sebesar harga jual. Harga jual adalaha perolehan/pembelian barang ditambah keuntungan yang disepakati. Apabila nasabah mengangsur utangnya, utang nasabah itu akan berkurang sebesar pembayaran angsuran yang dilakukan, jadi tidak membedakan lagi unsur pokok dan keuntungan. Sedangkan pada pembiayaan konsumen, utang nasabah adalah sebasar pokok kredit ditambah dengan bunga. Bila dibayar secara angsuran, utang nasabah akan berkurang sebesar pembayaran angsuran pokok kredit dan pembayaran bunga. Jadi, dalam pembiayaan konsumen dikenal adanya utang pokok dan hutang bunga. 
Menurut Dr. Muhammad Shabri Abdul Majid dalam artikelnya Islamic Banks and Investment Financing, Aggarwal dan Yousef (1996) menyebutkan bahwa salah satu kelemahan utama operasi perbankan dewasa ini, yaitu cara pembiayaan bank Islam masih didominasi oleh sistem mark up (menaikkan harga) berbanding sistem profit-loss sharing (bagi hasil). Dalam murabahah, pihak bank akan membeli barang sesuai dengan permintaan pelanggan, dengan pihak bank akan mengambil keuntungan melalui cara menaikkan harga jual, yang dibayar pelanggan sama, ada secara angsuran ataupun kredit. Inilah yang menyebabkan para pakar perbankan dan ekonomi Islam menentang sistem mark up. Sikap bank Islam yang tidak mau menghadapi risiko inilah yang menyebabkan praktek bank Islam masih dianggap menyerupai dan bahkan 'sama' dengan cara kerja bank konvensional. Akibatnya banyak umat Islam yang masih meragukan kesahihan bank Islam sebagai institusi untuk menyimpan dan meminjam vang yang tepat berlandaskan sunatullah.

\section{Pengertian Nasabah}

Berdasarkan

Undang-Undang Republik Indonesia Nomor 21 Tahun 2008 tentang Perbankan Syariah, nasabah adalah pihak yang menggunakan jasa bank syariah dan atau Unit Usaha Syariah.

\section{Faktor-Faktor yang Mempengaruhi Keputusan Pembelian}

Dalam pemasaran jasa dengan hanya mengandalkan 4P (product, price, promotion, place), perusahaan tidak dapat memahami hubungan timbal balik antara aspek-aspek kunci dalam bisnis jasa. People, process dan physical evidence ditambahkan dalam bauran pemasaran jasa dikarenakan sifat dan karakteristik unik yang dimiliki oleh jasa itu sendiri. Menurut Zeithaml dan Bitner (2003) Unsur-unsur pemasar itu terdiri dari:

\section{Product (Produk)}

Produk adalah segala sesuatu yang dapat di tawarkan meliputi barang fisik, jasa, orang, tempat, organisasi, dan gagasan.

2. Price (Harga)

Yaitu jumlah uang yang harus dibayar oleh pelanggan untuk memperoleh produk atau jasa.

3. Promotion (Promosi)

Aktivitas yang mengkomunikasikan produk dan membujuk pelanggan sasaran untuk membelinya.

4. Place (Tempat Atau Lokasi) Termasuk aktivitas perusahaan untuk menyalurkan produk atau jasa yang tersedia bagi konsumen.

5. People (Orang)

Adalah semua pelaku yang memainkan sebagai penyajian jasa dan karenanya mempengaruhi persepsi pembeli. Yang termasuk dalam elemen ini adalah personel perusahaan dan konsumen lain dalam lingkungan jasa.

6. Process (Proses)

Meliputi prosedur, tugas-tugas, jadwaljadwal, mekanisme, kegiatan dan 
rutinitas dimana suatu produk atau jasa disampaikan kepada pelanggan

7. Physical Evidence (Bukti Fisik)

Merupakan lingkungan fisik dimana jasa disampaikan, perusahaan jasa dan konsumennya berinteraksi dan setiap komponen yang berwujud memfasilitasi penampilan atau komunikasi jasa tersebut.

Sedangkan menurut Phiplip Kotler (2003) perilaku pembelian konsumen dipengaruhi oleh empat fa, yaitu faktor budaya, faktor sosial, faktor pribadi dan faktor psikologis.

\section{Penelitian Sebelumnya}

Penelitian ini merujuk pada penelitian sebelumnya sebagai bahan referensi. Lutfi Ibnunajjar (2012) dalam penelitiannya yang berjudul "Mengapa Pembiayaan Murabahah Pada Bank Muamalat Indonesia Cabang Surabaya Dominan?" menguraikan pengertian murabahah dalam perspektif Islam, aplikasi murabahah di dalam perbankan syariah, keunggulan murabahah dibandingkan produk bank syariah yang lain dan menjelaskan sebab dominannya pembiayaan murabahah di Bank Muamalat Indonesia Cabang Surabaya.

\section{METODE PENELITIAN}

\section{Pendekatan Penelitian}

Penelitian ini menggunakan metode kualitatif karena menginterpretasikan, menyoroti dan menjelaskan suatu fenomena unik. Dan penelitian ini sulit diukur oleh penelitian dengan pendekatan kuantitatif, karena berkaitan dengan memahami pengalaman orangorang terkait dengan fenomena yang terjadi. Moleong (2007:6) mendefinisikan penelitian kualitatif yaitu penelitian yang bermaksud untuk memahami fenomena tentang apa yang dialami oleh subyek penelitian misalnya perilaku, persepsi, motivasi, tindakan, dan lain-lain, secara holistic dan dengan cara mendeskripsikan dalam bentuk kata-kata dan bahasa, pada suatu konteksd khusus yang alamiah dan dengan memanfaatkan berbagai metode alamiah.

\section{Ruang Lingkup Penelitian}

Ruang lingkup penelitian terkait dengan rumusan masalah dalam penelitian ini. Rumusan masalah dalam penelitian ini adalah apa alasan nasabah non muslim memilih pembiayaan murabahah di Bank Bni Syariah Kc. Rungkut Surabaya. Rumusan masalah tersebut akan menjadi acuan oleh peneliti dalam menentukan ruang lingkup penelitian. Ruang lingkup penelitian terbatas memfokuskan pada pembiayaan murabahah dibandingkan dengan pembiayaan lainnya dan mencari jawaban alasan nasabah non muslim memilih pembiayaan tersebut.

\section{Jenis dan Sumber Data}

Sumber data yang digunakan untuk penelitian ini adalah data primer dan data sekunder. Data primer adalah data yang didapatkan langsung dari sumber informasi yang bersangkutan. Menurut 
Hasan (2002:82) data primer adalah data yang diperoleh atau dikumpulkan langsung di lapangan oleh orang yang melakukan penelitian atau bersangkutan memerlukannya. Sedangkan data sekunder merupakan data yang tidak langsung memberikan data kepada pengumpul data, misalnya lewat orang lain ataupun dokumen (Sugiyono, 2013:62).

\section{Teknik Keabsahan Data}

Penilaian keabsahan penelitian kualitatif terjadi pada waktu proses pengumpulan data, dan untuk menentukan keabsahan data diperlukan teknik pemeriksaan. Pelaksanaan teknik pemeriksaan didasarkan atas sejumlah kriteria tertentu dan dalam memeriksa keabsahan data yang diperoleh maka penulis menggunakan teknik triangulasi data.

Menurut Sugiyono (2013), teknik triangulasi data terdapat 3 macam, yaitu triangulasi sumber, triangulasi teknik dan triangulasi waktu. Dalam penelitian ini, peneliti menggunakan triangulasi sumber yang berasal pegawai BNI Syariah Kc. Rungkut Surabaya. Triangulasi sumber bertujuan untuk mencocokkan jawaban antara pegawai dengan nasabah apakah sesuai atau tidak.

Dalam penelitian ini, peneliti menggunakan triangulasi sumber yang berasal pegawai BNI Syariah Kc. Rungkut Surabaya. Triangulasi sumber bertujuan untuk mencocokkan jawaban antara pegawai dengan nasabah apakah sesuai atau tidak.

\section{Teknik Analisis Data}

Dalam penelitian ini menggunakan metode purposive sampling. Metode purposive sampling adalah teknik pengambialan informan sumber data dengan pertimbangan tertentu (Sugiyono, 2007:2008). Sedangkan analisis data yang digunakan dalam penelitian ini adalah reduksi data, penyajian data, dan menyimpulkan data.

\section{HASIL DAN PEMBAHASAN}

\section{Sejarah BNI Syariah}

BNI Syariah didirikan pada tanggal 19 Juni 2010 yang diresmikan oleh menteri keuangan Republik Indonesia DR. Bambang Sudibyo. Sedangkan BNI Syariah Kc. Rungkut Surabaya sendiri didirikan pada tanggal 3 Mei 2012. Sebagai langkah awal Unit Usaha Syariah pada BNI Syariah guna menyediakan layanan perbankan syariah bagi umat islam yang mayoritas sebagai agama terbesar di Indonesia dan juga sebagai tuntutan sebagai lembaga keuangan yang terbebas dari riba dengan sistem pengoprasiannya dengan sistem bagi hasil. BNI dengan bersungguh-sungguh menjalankan kegiatan usahanya dengan menghindar dari unsur riba.

\section{Karakteristik Informan}

Dalam penelitian ini, peneliti melakukan wawancara secara mendalam kepada beberapa informan supaya dapat mencapai temuan penelitian, teknik pengambilan data menggunakan teknik purposive sampling. 
Informan dalam penelitian ini berjumlah 9 informan. Dari 9 orang informan, 3 diantaranya merupakan pegawai BNI Syariah dan 6 diantaranya merupakan nasabah non muslim. Dengan rincian dalam tabel 1 .

Tabel 1.

Karakteristik Informan (Pegawai)

\begin{tabular}{|c|l|c|c|c|c|}
\hline $\begin{array}{c}\mathbf{N} \\
\mathbf{0}\end{array}$ & Nama & Umur & Jabatan & $\begin{array}{c}\text { Teknik } \\
\text { Sampling }\end{array}$ & $\begin{array}{c}\text { Tanggal } \\
\text { Wawan } \\
\text { cara }\end{array}$ \\
\hline 1 & Aditya Surya & 23 & $\begin{array}{c}\text { Account } \\
\text { Officer }\end{array}$ & $\begin{array}{c}\text { Purposive } \\
\text { Sampling }\end{array}$ & $\begin{array}{c}21 \\
\text { Agustus } \\
2014\end{array}$ \\
\hline 2 & Arif Dharma & 23 & $\begin{array}{c}\text { Account } \\
\text { Officer }\end{array}$ & $\begin{array}{c}\text { Purposive } \\
\text { Sampling }\end{array}$ & $\begin{array}{c}21 \\
\text { Agustus } \\
2014\end{array}$ \\
\hline 3 & $\begin{array}{l}\text { Diwiacita } \\
\text { Nanda } \\
\text { Dianto }\end{array}$ & 23 & Analis & $\begin{array}{c}\text { Purposive } \\
\text { Sampling }\end{array}$ & $\begin{array}{c}21 \\
\text { Agustus } \\
2014\end{array}$ \\
\hline
\end{tabular}

Sumber: Hasil Pengolahan data sekunder, 2014

Tabel 2.

Karakteristik Informan (Nasabah)

\begin{tabular}{|c|c|c|c|c|c|c|}
\hline $\begin{array}{l}\mathbf{N} \\
0\end{array}$ & Nama & $\begin{array}{l}u \\
m \\
u \\
r\end{array}$ & $\begin{array}{l}\text { Profesi / Usaha } \\
\text { yang dimiliki }\end{array}$ & $\begin{array}{c}\text { Jenis } \\
\text { Pembiay } \\
\text { aan }\end{array}$ & $\begin{array}{c}\text { Teknik } \\
\text { Sampling }\end{array}$ & $\begin{array}{c}\text { Tanggal } \\
\text { Wawanca } \\
\text { ra }\end{array}$ \\
\hline 4 & Darman & $\begin{array}{l}5 \\
4\end{array}$ & $\begin{array}{l}\text { Pengusaha } \\
\text { Kelapa Sawit }\end{array}$ & $\begin{array}{l}\text { Murabah } \\
\text { ah }\end{array}$ & $\begin{array}{l}\text { Purposive } \\
\text { Sampling }\end{array}$ & $\begin{array}{c}27 \\
\text { Agustus } \\
2014\end{array}$ \\
\hline 5 & $\begin{array}{l}\text { Joko } \\
\text { Alex }\end{array}$ & $\begin{array}{l}2 \\
8\end{array}$ & $\begin{array}{l}\text { Bengkel Sepeda } \\
\text { Motor }\end{array}$ & $\begin{array}{l}\text { Murabah } \\
\text { ah }\end{array}$ & $\begin{array}{l}\text { Purposive } \\
\text { Sampling }\end{array}$ & $\begin{array}{c}29 \\
\text { Agustus } \\
2014 \\
\end{array}$ \\
\hline 6 & $\mathrm{Aji}$ & $\begin{array}{l}5 \\
0\end{array}$ & Kedai Bakso & $\begin{array}{l}\text { Murabah } \\
\text { ah }\end{array}$ & $\begin{array}{l}\text { Purposive } \\
\text { Sampling }\end{array}$ & $\begin{array}{c}2 \\
\text { Septemb } \\
\text { er } 2014\end{array}$ \\
\hline 7 & $\begin{array}{l}\text { Bu } \\
\text { Kristiowat } \\
\text { i }\end{array}$ & $\begin{array}{l}5 \\
2\end{array}$ & $\begin{array}{l}\text { Isi Ulang Air } \\
\text { Minum }\end{array}$ & $\begin{array}{l}\text { Murabah } \\
\text { ah }\end{array}$ & $\begin{array}{l}\text { Purposive } \\
\text { Sampling }\end{array}$ & $\begin{array}{c}3 \\
\text { Septemb } \\
\text { er } 2014 \\
\end{array}$ \\
\hline 8 & $\begin{array}{l}\mathrm{Ni} \\
\text { Wayan }\end{array}$ & $\begin{array}{l}4 \\
8\end{array}$ & Toko Bangunan & $\begin{array}{c}\text { Murabah } \\
\text { ah }\end{array}$ & $\begin{array}{l}\text { Purposive } \\
\text { Sampling }\end{array}$ & $\begin{array}{c}3 \\
\text { Septemb } \\
\text { er } 2014\end{array}$ \\
\hline 9 & $\begin{array}{l}\text { Tan Ting } \\
\text { Sui }\end{array}$ & $\begin{array}{l}5 \\
0\end{array}$ & Percetakan & $\begin{array}{c}\text { Murabah } \\
\text { ah }\end{array}$ & $\begin{array}{l}\text { Purposive } \\
\text { Sampling }\end{array}$ & $\begin{array}{c}4 \\
\text { Septemb } \\
\text { er } 2014\end{array}$ \\
\hline
\end{tabular}

Sumber: Hasil Pengolahan data Primer, 2014

Peneliti akan membandingkan jawaban informan dari sudut pandang pegawai dan nasabah non muslim sebagai teknik keabsahan data yaitu teknik triangulasi data agar mendapatkan jawaban yang benar-benar valid.

\section{Hasil Penelitian}

Murabahah menjadi sumber pendapatan paling besar pada BNI Syariah. Hal ini dapat dibuktikan dengan laporan keuangan dari BNI Syariah dalam 4 tahun terakhir yang menunjukkan pembiayaan murabahah meningkat pada setiap tahunnya. Wawancara yang dilakukan kepada pegawai dan nasabah non muslim BNI Syariah digunakan untuk mengetahui faktor-faktor yang melatar belakangi nasabah non muslim memilih pembiayaan murabahah. Tabel 3. menunjukkan alasana nasabah non muslim memilih pembiayaan murabahah di BNI Syariah Kc. Rungkut Surabaya dari sudut pandang pegawai BNI Syariah.

Tabel 3.

Alasan Nasabah Non Muslim Memilih Pembiayaan Murabahah Dari Sudut Pandang Pegawai BNI Syariah

\begin{tabular}{|l|l|l|}
\hline Informan & $\begin{array}{c}\text { Alasan } \\
\text { Nasabah Non } \\
\text { Muslim Memilih } \\
\text { Pembiayaan } \\
\text { Murabahah }\end{array}$ & \multicolumn{1}{c|}{ Keterangan } \\
\hline $\begin{array}{l}\text { Informan } \\
\text { Angsuran setiap } \\
\text { bulan tetap }\end{array}$ & $\begin{array}{l}\text { Tidak ada kenaikan } \\
\text { terhadap angsuran } \\
\text { setiap bulannya karena } \\
\text { tidak mengikuti aturan } \\
\text { suku bunga }\end{array}$ \\
\hline 2 & Fleksibel & $\begin{array}{l}\text { Tujuannya bisa banyak, } \\
\text { bisa untuk membeli } \\
\text { tanah, kalau di bank lain } \\
\text { belum tentu bisa. }\end{array}$ \\
\hline 3 & Sistemnya & $\begin{array}{l}\text { Murabahah layaknya jual } \\
\text { beli barang, nasabah } \\
\text { butuhnya apa, pihak } \\
\text { bank yang memberikan } \\
\text { pembiayannya. }\end{array}$ \\
\hline
\end{tabular}

Sumber : Hasil Pengolahan Data Sekunder, 2014

Dari hasil wawancara yang telah dilakukan kepada pegawai BNI Syariah memiliki jawaban yang semuanya berbeda, hal ini mungkin dikarenakan ketiga informan tersebut bukan pelaku utama dalam pembiayaan ini, mereka hanya fasilitator antara nasabah dengan bank. Jawaban ketiga informan tersebut akan dibandingkan dengan jawaban dari nasabah non muslim, apakah terdapat persamaan atau tidak.

Tabel 4. menunjukkan alasan nasabah non muslim memilih pembiayaan murabahah di BNI Syariah Kc. Rungkut 
Surabaya. Dari Tabel 4. terlihat beberapa persamaan jawaban antara nasabah non muslim dan jawaban dari sudut pandang pegawai BNI Syariah, kemudian peneliti merangkum bahwa faktor-faktor yang melatar belakangi nasabah non muslim memilih pembiayaan pembiayaan di $\mathrm{BNI}$ Syariah yang pertama adalah karena prosesnya mudah dan cepat, hal ini bisa diartikan karena skema pembiayaan yang sederhana, yang kedua karena dari pegawai BNI Syariah terjun langsung ke lapangan untuk mencari nasabah yang memiliki usaha mikro, hal ini dapat dikatakan promosi yang dilakukan oleh BNI Syariah sangat gencar, yang ketiga saling menguntungkan.

Tabel 4.

Alasan Nasabah Non Muslim Memilih Pembiayaan Murabahah

\begin{tabular}{|c|c|c|}
\hline Informan & $\begin{array}{l}\text { Alasan Memilih } \\
\text { Pembiayaan } \\
\text { murabahah di BNI } \\
\text { Syariah }\end{array}$ & Keterangan \\
\hline $\begin{array}{c}\text { Informan } \\
4\end{array}$ & $\begin{array}{l}\text { Prosedurnya tidak } \\
\text { rumit, waktu tidak } \\
\text { panjang, saling } \\
\text { menguntungkan. }\end{array}$ & $\begin{array}{l}\text { Karena nasabah } \\
\text { hanya sekali ke } \\
\text { bank, kemudian } \\
\text { besoknya } \\
\text { langsung diproses } \\
\text { oleh bank. }\end{array}$ \\
\hline $\begin{array}{c}\text { Informan } \\
5\end{array}$ & $\begin{array}{l}\text { Prosesnya mudah } \\
\text { dan cepat, } \\
\text { kedekatan pihak } \\
\text { bank dengan } \\
\text { masyarakat. }\end{array}$ & $\begin{array}{lr}\text { Karena pegawai } \\
\text { bank } & \text { terjun } \\
\text { langsung } & \text { ke } \\
\text { masyarakat } & \text { kecil } \\
\text { untuk mencari } \\
\text { nasabah } & \text { yang } \\
\text { memiliki } & \text { usaha } \\
\text { kecil. } & \\
\end{array}$ \\
\hline $\begin{array}{c}\text { Informan } \\
6\end{array}$ & $\begin{array}{l}\text { Didatangi } \\
\text { marketing, } \\
\text { Prosesnya mudah } \\
\text { dan cepat, saling } \\
\text { menguntungkan. }\end{array}$ & $\begin{array}{l}\text { Karena apabila } \\
\text { nasabah tidak } \\
\text { sempat ke bank } \\
\text { untuk } \\
\text { mengangsur, } \\
\text { pihak bank bisa } \\
\text { langsung } \\
\text { mendebit } \\
\text { tabungan } \\
\text { nasabah. }\end{array}$ \\
\hline $\begin{array}{c}\text { Informan } \\
7\end{array}$ & $\begin{array}{l}\text { Didatangi } \\
\text { marketing, } \\
\text { prosesnya cepat, } \\
\text { saling } \\
\text { menguntungkan. }\end{array}$ & $\begin{array}{l}\text { Karena ditawari } \\
\text { langsung oleh } \\
\text { marketing yang } \\
\text { kebetulan } \\
\text { tersesat di sekitar } \\
\text { lokasi usaha }\end{array}$ \\
\hline Informan & Didatangi & Karena nasabah \\
\hline
\end{tabular}

\begin{tabular}{|c|c|c|}
\hline 8 & $\begin{array}{c}\text { marketing, } \\
\text { prosesnya cepat, } \\
\text { saling } \\
\text { menguntungkan. }\end{array}$ & $\begin{array}{l}\text { tidak perlu repot- } \\
\text { repot ke bank, } \\
\text { dari banknya } \\
\text { sendiri yang selalu } \\
\text { mendatangi } \\
\text { rumah nasabah } \\
\text { untuk proses } \\
\text { pengajuan } \\
\text { pembiayaan } \\
\text { tersebut. }\end{array}$ \\
\hline $\begin{array}{c}\text { Informan } \\
9\end{array}$ & $\begin{array}{l}\text { Didatangi } \\
\text { marketing, } \\
\text { prosesnya cepat, } \\
\text { saling } \\
\text { menguntungkan. }\end{array}$ & $\begin{array}{l}\text { Karena nasabah } \\
\text { merasa tidak } \\
\text { dirugikan, bagi } \\
\text { seorang } \\
\text { pengusaha non } \\
\text { muslim yang } \\
\text { dicari hanyalah } \\
\text { keuntungan. }\end{array}$ \\
\hline
\end{tabular}

Sumber: Hasil Pengolahan Data Primer, 2014

Alasan nasabah non muslim memilih pembiayaan murabahah di BNI Syariah Kc. Rungkut Surabaya telah diuraikan sebelumnya di Tabel 4, kemudian jika dibandingkan dengan faktor-faktor yang mempengaruhi keputsan pembelian ditinjau dari bauran pemasaran (marketing mix) menurut Zeithaml dan Bitner (2003), maka hasilnya ada di Tabel 5.

Berdasarkan Tabel 5, dapat dilihat dari teori faktor-faktor yang mempengaruhi penjualan ditinjau dari bauran pemasaran menurut Zeithaml dan Bitner (2003), faktor yang mempengaruhi alasan nasabah non muslim memilih pembiayaan murabahah di BNI Syariah Kc. Rungkut Surabaya adalah process dan promotion saja. Sedangkan apabila dibandingkan dengan teori keputusan pembelian menurut Philip Kotler (2003), maka hasilnya ada di Tabel 6.

Tabel 5.

Alasan Nasabah Non Muslim Memilih

Pembiayaan Murabahah Menurut Teori Faktor-Faktor yang Mempengarui Keputusan Pembelian (Zeithaml dan Bitner) 


\begin{tabular}{|c|c|c|c|}
\hline $\begin{array}{l}\mathrm{l} \\
\mathrm{n} \\
\mathrm{f} \\
\mathrm{o} \\
\mathrm{r} \\
\mathrm{m} \\
\mathrm{a} \\
\mathrm{n}\end{array}$ & $\begin{array}{l}\text { Alasan Nasabah } \\
\text { Non Muslim } \\
\text { Memilih } \\
\text { Pembiayaan } \\
\text { Murabahah }\end{array}$ & $\begin{array}{l}\text { Teori Faktor- } \\
\text { Faktor yang } \\
\text { Mempengar } \\
\text { ui Keputusan } \\
\text { Pembelian }\end{array}$ & Keterangan \\
\hline 4 & $\begin{array}{l}\text { Prosedurnya tidak } \\
\text { rumit, waktu tidak } \\
\text { panjang, saling } \\
\text { menguntungkan. }\end{array}$ & Process & $\begin{array}{l}\text { Karena nasabah hanya } \\
\text { sekali ke bank, kemudian } \\
\text { besoknya langsung } \\
\text { diproses oleh bank. } \\
\end{array}$ \\
\hline 5 & $\begin{array}{l}\text { Prosesnya mudah } \\
\text { dan cepat, } \\
\text { kedekatan pihak } \\
\text { bank dengan } \\
\text { masyarakat. }\end{array}$ & $\begin{array}{l}\text { Process, } \\
\text { Promotion }\end{array}$ & $\begin{array}{lrr}\text { Karena pegawai } & \text { bank } \\
\text { terjun langsung } & \text { ke } \\
\text { masyarakat kecil } & \text { untuk } \\
\text { mencari nasabah yang } \\
\text { memiliki usaha kecil. }\end{array}$ \\
\hline 6 & $\begin{array}{l}\text { Didatangi } \\
\text { marketing, } \\
\text { Prosesnya mudah } \\
\text { dan cepat, saling } \\
\text { menguntungkan. }\end{array}$ & $\begin{array}{l}\text { Process, } \\
\text { Promotion }\end{array}$ & $\begin{array}{l}\text { Karena apabila nasabah } \\
\text { tidak sempat ke bank } \\
\text { untuk mengangsur, pihak } \\
\text { bank bisa langsung } \\
\text { mendebit } \\
\text { nasabah. }\end{array}$ \\
\hline 7 & $\begin{array}{l}\text { Didatangi } \\
\text { marketing, } \\
\text { prosesnya cepat, } \\
\text { saling } \\
\text { menguntungkan. }\end{array}$ & $\begin{array}{l}\text { Process, } \\
\text { Promotion }\end{array}$ & $\begin{array}{l}\text { Karena ditawari langsung } \\
\text { oleh marketing yang } \\
\text { kebetulan tersesat di } \\
\text { sekitar lokasi usaha }\end{array}$ \\
\hline 8 & $\begin{array}{l}\text { Didatangi } \\
\text { marketing, } \\
\text { prosesnya cepat, } \\
\text { saling } \\
\text { menguntungkan. }\end{array}$ & $\begin{array}{c}\text { Process, } \\
\text { Promotion }\end{array}$ & $\begin{array}{l}\text { Karena nasabah tidak } \\
\text { perlu repot-repot ke bank, } \\
\text { dari banknya sendiri yang } \\
\text { selalu mendatangi rumah } \\
\text { nasabah untuk proses } \\
\text { pengajuan pembiayaan } \\
\text { tersebut. }\end{array}$ \\
\hline 9 & $\begin{array}{l}\text { Didatangi } \\
\text { marketing, } \\
\text { prosesnya cepat, } \\
\text { saling } \\
\text { menguntungkan. }\end{array}$ & $\begin{array}{l}\text { Process, } \\
\text { Promotion }\end{array}$ & $\begin{array}{l}\text { Karena nasabah merasa } \\
\text { tidak dirugikan, bagi } \\
\text { seorang pengusaha non } \\
\text { muslim yang dicari } \\
\text { hanyalah keuntungan. }\end{array}$ \\
\hline
\end{tabular}

Sumber: Hasil Pengolahan Data Primer,

2014

Dari 4 teori faktor-fakor yang mempengaruhi keputusan pembelian di menurut Philip Kotler, faktor yang paling mempengaruhi adalah faktor psikologis dari segi persepsi yang ditunjukkan oleh 4 dari 6 nasabah.

\section{A. Skema Pembiayaan yang Sederhana}

Salah satu faktor utama yang melatar belakangi nasabah non muslim memilih pembiayaan di BNI Syariah adalah skema pembiayaan yang sederhana. Murabahah adalah produk pembiayaan dengan skema yang paling mudah sehingga banyak diminati oleh nasabah non muslim, dengan angsuran dan margin yang sudah ditetapkan mempermudah BNI Syariah untuk menyalurkan produk murabahah. Hal ini berbeda dengan produk pembiayaan yang lain misalnya mudharabah dan musyarakah yang menggunakan skim bagi hasil yang skemanya lebih rumit dan perhitungan nisbah bagi hasil yang sewaktu-waktu dapat berubah.

Tabel 6.

Alasan Nasabah Non Muslim Memilih Pembiayaan Murabahah Menurut Teori Faktor-Faktor yang Mempengarui Keputusan Pembelian (Philip Kotler)

\begin{tabular}{|c|c|c|c|}
\hline $\begin{array}{c}\text { Info } \\
\text { rma } \\
n\end{array}$ & $\begin{array}{l}\text { Alasan Nasabah } \\
\text { Non Muslim } \\
\text { Memilih } \\
\text { Pembiayaan } \\
\text { Murabahah } \\
\end{array}$ & $\begin{array}{c}\text { Teori Faktor- } \\
\text { Faktor yang } \\
\text { Mempengar } \\
\text { ui Keputusan } \\
\text { Pembelian } \\
\end{array}$ & Keterangan \\
\hline 4 & $\begin{array}{l}\text { Prosedurnya } \\
\text { tidak rumit, } \\
\text { waktu tidak } \\
\text { panjang, saling } \\
\text { menguntungkan }\end{array}$ & $\begin{array}{l}\text { Psikologis } \\
\text { (motivasi) }\end{array}$ & $\begin{array}{l}\text { Karena nasabah } \\
\text { memang sedang dalam } \\
\text { kebutuhan untuk } \\
\text { pinjaman dana. }\end{array}$ \\
\hline 5 & $\begin{array}{c}\text { Prosesnya } \\
\text { mudah dan } \\
\text { cepat, } \\
\text { kedekatan pihak } \\
\text { bank dengan } \\
\text { masyarakat. } \\
\end{array}$ & $\begin{array}{l}\text { Faktor Sosial } \\
\text { (kelompok } \\
\text { acuan) }\end{array}$ & 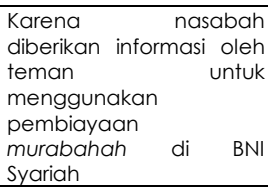 \\
\hline 6 & $\begin{array}{l}\text { Didatangi } \\
\text { marketing, } \\
\text { Prosesnya } \\
\text { mudah dan } \\
\text { cepat, saling } \\
\text { menguntungkan }\end{array}$ & $\begin{array}{l}\text { Psikologis } \\
\text { (persepsi) }\end{array}$ & $\begin{array}{ll}\text { Karena } & \text { nasabah } \\
\text { termotivasi oleh promosi } \\
\text { marketing sehingga } \\
\text { mempengaruhi } \\
\text { persepsinya tentang } \\
\text { bank syariah }\end{array}$ \\
\hline 7 & $\begin{array}{l}\text { Didatangi } \\
\text { marketing, } \\
\text { prosesnya } \\
\text { cepat, saling } \\
\text { menguntungkan } \\
\text {. }\end{array}$ & $\begin{array}{l}\text { Psikologis } \\
\text { (persepsi) }\end{array}$ & $\begin{array}{lr}\text { Karena } & \text { ditawari } \\
\text { langsung oleh marketing } \\
\text { yang kebetulan tersesat } \\
\text { di sekitar lokasi usaha } \\
\text { sehinggar nasabah } \\
\text { termotivasi r untuk } \\
\text { menggunaka } \\
\text { pembiayaan } \\
\text { murabahah } \\
\end{array}$ \\
\hline 8 & $\begin{array}{l}\text { Didatangi } \\
\text { marketing, } \\
\text { prosesnya } \\
\text { cepat, saling } \\
\text { menguntungkan } \\
\text {. }\end{array}$ & $\begin{array}{l}\text { Psikologis } \\
\text { (persepsi) }\end{array}$ & $\begin{array}{lr}\text { Karena } & \text { ditawari } \\
\text { langsung oleh marketing } \\
\text { yang kebetulan tersesat } \\
\text { di sekitar lokasi usaha } \\
\text { sehinggar nasabah } \\
\text { termotivasi r untuk } \\
\text { menggunaka } \\
\text { pembiayaan } \\
\text { murabahah } \\
\end{array}$ \\
\hline 9 & $\begin{array}{l}\text { Didatangi } \\
\text { marketing, } \\
\text { prosesnya } \\
\text { cepat, saling } \\
\text { menguntungkan } \\
\text {. }\end{array}$ & $\begin{array}{l}\text { Psikologis } \\
\text { (persepsi) }\end{array}$ & 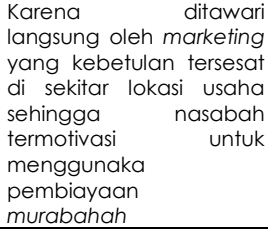 \\
\hline
\end{tabular}

B. Promosi yang Menyeluruh

Faktor kedua adalah promosi pembiayaan mikro yang menyeluruh. Dalam rangka membantu masyarakat yang berada di daerah pinggiran untuk 
memperoleh pembiayaan bagi usahausaha kecil, seperti pedagang pasar tradisional atau industri rumah tangga, BNI Syariah melakukan promosi besar-besaran hingga ke pelosok-pelosok daerah untuk membidik pengusaha di level mikro. Pasalnya potensinya masih sangat besar, terutama di daerah-daerah perbatasan. Pengelolaan unit mikro di daerah pinggiran jauh lebih mudah. Nasabah hanya perlu memiliki satu lokasi usaha yang sudah berjalan selama minimal setahun. BNI Syariah tidak mewajibkan jaminan fisik. Misalnya seorang pemilik warung megajukan pembiayaan, ketika jatuh tempo pihak BNI masih bisa mengejar kerumahnya, karena lokasi usahanya tidak akan berubah.

\section{Akad yang Saling Menguntungkan}

$$
\text { Pembiayaan }
$$

murabahah memberikan keuntungan baik bagi pihak bank maupun nasabah. Pembiayaan murabahah jugamerupakan sumber penerimaan utama dibandingkan dengan pembiayaan lain seperti musyarakah dan mudharabah. BNI Syariah tidak terlalu khawatir dengan risiko turunnya pendapatan karena murabahah mengalami peningkatan pada setiap tahunnya. Bagi pihak nasabah sendiri, murabahah menjadi pilihan utama pada saat pengajuan pembiayaan karena risiko pada pembiayaan ini lebih rendah dibandingkan dengan pembiayaan yang menggunakan skim bagi hasil seperti musyarakah dan mudharabah hal ini dikarenakan pada pembiayaan yang menggunakan skim bagi hasil akan mengalami proses evaluasi setiap 2 tahun dan masih tergantung pada suku bunga Bank Indonesia. Jika suku bunga naik maka prosentase bagi hasil yang ditetapkan pada awal akad dapat berubah.

\section{Manfaat Setelah \\ Pembiayaan Murabahah}

Mendapatkan

Setelah

mendapatkan pembiayaan dari BNI Syariah harusnya terdapat perbedaan yang dirasakan oleh para nasabah. Manfaat yang dirasakan nasabah dijelaskan dalam tabel 7 berikut :

Tabel 7.

Manfaat Setelah Mendapat Pembiayaan Murabahah

\begin{tabular}{|c|c|c|}
\hline Informan & $\begin{array}{l}\text { Manfaat } \\
\text { Setelah } \\
\text { Mendapat } \\
\text { Pembiayaan } \\
\text { Murabahah }\end{array}$ & Keterangan \\
\hline $\begin{array}{c}\text { Informan } \\
4\end{array}$ & $\begin{array}{l}\text { Usaha } \\
\text { semakin } \\
\text { berkembang, } \\
\text { pendapatan } \\
\text { berkurang }\end{array}$ & $\begin{array}{l}\text { Dari segi pendapatan untuk } \\
\text { keluarga jadi kecil karena } \\
\text { memfokuskan angsuran } \\
\text { tiap bulannya, tapi untuk } \\
\text { kedepannya akan untung } \\
\text { apabila angsuran telah } \\
\text { lunas. }\end{array}$ \\
\hline $\begin{array}{c}\text { Informan } \\
5\end{array}$ & $\begin{array}{l}\text { Belum bisa } \\
\text { dirasakan }\end{array}$ & $\begin{array}{l}\text { Informan yang satu ini } \\
\text { belum bisa mencapai } \\
\text { keinginannya membeli } \\
\text { rumah untuk kos-kosan } \\
\text { karena pembiayaan yang } \\
\text { cair tidak sesuai yang } \\
\text { diharapkan }\end{array}$ \\
\hline $\begin{array}{l}\text { Informan } \\
6\end{array}$ & $\begin{array}{l}\text { Bisa } \\
\text { merenovasi } \\
\text { tempat } \\
\text { usaha }\end{array}$ & $\begin{array}{l}\text { Tempat usaha yang semula } \\
\text { hanya terop kini sudah } \\
\text { dibangun sehingga } \\
\text { membuat nyaman } \\
\text { pelanggan }\end{array}$ \\
\hline $\begin{array}{l}\text { Informan } \\
7\end{array}$ & Relatif & $\begin{array}{l}\text { Besar kecilnya keuntungan } \\
\text { yang diperoleh tergantung } \\
\text { bagaimana penguasaha }\end{array}$ \\
\hline
\end{tabular}




\begin{tabular}{|c|l|l|}
\hline & & menjalankan usahanya \\
\hline $\begin{array}{c}\text { Informan } \\
8\end{array}$ & $\begin{array}{l}\text { Tokonya } \\
\text { semakin } \\
\text { penuh }\end{array}$ & $\begin{array}{l}\text { Nasabah bisa membeli } \\
\text { bahan bangunan lebih } \\
\text { banyak karena modal yang } \\
\text { didapat dari bank }\end{array}$ \\
\hline \multirow{3}{\text{Informan}}{$\begin{array}{l}\text { Usaha } \\
9\end{array}$} & $\begin{array}{l}\text { semakin } \\
\text { berkembang, } \\
\text { beban }\end{array}$ & $\begin{array}{l}\text { dikarenakan pendapatan } \\
\text { yang diperolah harus } \\
\text { dikurangi oleh angsuran } \\
\text { yang harus dibayar ke } \\
\text { bertambah }\end{array}$ \\
\hline
\end{tabular}

Sumber: Hasil Pengolahan Data Primer,

2014

V. SIMPULAN

\section{Simpulan}

Berdasarkan analisis dan pembahasan maka diperoleh simpulan bahwa alasan nasabah non muslim memilih pembiayaan murabahah di BNI Syariah adalah:

1. Skema pembiayaan yang sederhana, bagi nasabah non muslim proses yang mudah dan cepat merupakan daya tarik utama mereka memlilih pembiayaan murabahah.

2. Promosi pembiayaan mikro yang menyeluruh membuat nasabah non muslim tidak perlu jauh-jauh mendatangi bank, karena marketing bank yang akan mendatangi nasabah.

3. Akad yang saling menguntungkan, bagi pengusaha non muslim asalkan mereka tidak merasa dirugikan maka mereka akan mengambil pembiayaan tersebut tanpa pikir panjang.

Sedangkan manfaat yang didapat setelah adanya pembiayaan murabahah adalah :
1. Usaha semakin berkembang karena telah mendapat pembiayaan.

2. Relatif, karena besar kecilnya keuntungan tergantung bagaimana menjalankan usahanya.

3. Belum Bisa dirasakan

4. Beban bertambah karena harus menganggur setiap bulannya.

\section{Saran}

1. Bagi BNI Syariah, dapat menjelaskan lebih rinci perbedaan margin dan suku bunga, karena banyak nasabah non muslim yang merasa tidak ada bedanya bank syariah dengan bank konvensional.

2. Untuk peneliti selanjutnya, untuk dapat meneliti alasan nasabah non muslim memilih produk lain seperti musyarakah, mudharabah atau gadai emas.

\section{DAFTAR PUSTAKA}

Antonio, Muhammad Syafi'i. 2001. Bank Syariah: Dari Teori ke Praktik. Jakarta: Gema Insani.

Dewan Syariah Nasional MUI dan PSAK Np. 106

Fatwa DSN-MUI Nomor 04/DSNMUI/IV/2000 tentang Murabahah

Karim, Adiwarman. 2007. Bank Islam: Analisis Fiqih dan Keuangan. Edisi Ketiga. Jakarta: PT Grafindo Persada.

Moleong, Lexy J. 2007. Metodologi Penelitian Kualitatif. Bnadung: Remaja Rosdakarya. 
Muhammad. 2002. Manajemen Bank Syariah. Yogyakarta: AMP YKPN

Muhamad. 2006. Teknik Perhitungan Bagi Hasil dan Profit Margin pada Bank Syariah. Edisi Ketiga. Yogyakarta: UII Press.

Nazir, Moh. 2003. Metode Penelitian. Jakarta: Ghalia Indonesia.

Rivai, Veithzal \& Andria.2008. Islamic Financial Management. Jakarta: PT RajaGrafindo Persada.

Ryandono, Muhammad Nafik Hadi. 2009. Benarkah Bunga Haram?. Surabaya: Amanah Pustaka.

Ryandono. Muhammad Nafik Hadi. 2008. Bursa Efek \& Investasi syari'ah. Surabaya: CIEBERD

Ryandono, Muhammad Nafik Hadi. 2008. Modul disajikan dalam Pelatihan Lembaga Kevangan Syariah. Islamic Finance Development Institute (IFDI). Diolah

Statistik Perbankan Syariah (SPS). 2008. Jaringan Kantor Perbankan Syariah Indonesia.

Statistik Perbankan Syariah (SPS). 2009. Jaringan Kantor Perbankan Syariah Indonesia. (online)

http://www.bi.go.id/id/statistik/perbankan /syariah/Documents/2c79415689h4 7926eacaf0bc425d5fa93Desember 2008.pdf

Statistik Perbankan Syariah (SPS). 2010. Jaringan Kantor Perbankan Syariah Indonesia. (online)

http://www.bi.go.id/id/statistik/perbankan /syariah/Documents/79+5gr15b56c
8426eacaf0bc425d457qbc9Desem ber2010.pdf

Statistik Perbankan Syariah (SPS). 2011. Jaringan Kantor Perbankan Syariah Indonesia. (online)

http://www.bi.go.id/id/statistik/perbankan /syariah/Documents/9u723df5b562 lu426eacafObc4ft9378i67Desembe r2011.pdf

Statistik Perbankan Syariah (SPS). 2012. Jaringan Kantor Perbankan Syariah Indonesia. (online)

http://www.bi.go.id/id/statistik/perbankan /syariah/Documents/2c79415b56c 84i0l3acaf0bc425d5fa93Desember 2012.pdf

Statistik Perbankan Syariah (SPS). 2013. Jaringan Kantor Perbankan Syariah Indonesia. (online)

http://www.bi.go.id/id/statistik/perbankan /syariah/Documents/307ut415bkj92 6eacaf0bc425cz5d93Desember201 3.pdf

Statistik Perbankan Syariah (SPS). 2014. Jaringan Kantor Perbankan Syariah Indonesia. (online)

http://www.bi.go.id/id/statistik/perbankan /syariah/Documents/2c79415b56c 8026eacaf0bc425d5fa93Juni2014.p df

Sugiyono. 2008. Metode Penelitian Pendidikan Pendekatan Kuantitatif, Kualitatif, dan R\&D. Bandung: Alfabeta.

Sugiyono. 2013. Metode Penelitian Pendidikan Pendekatan Kuantitatif, Kualitatif, dan R\&D. Bandung: Alfabeta. 
Surifah. 2002. Kinerja Keuangan Perbankan

Swasta Nasional. JAAI, (Online),

Volume

6 ,

(http://journal.uii.ac.id/index.php/J

AAl/article/viewFile/854/782,

diakses 23 maret 2011).

Undang-undang No. 21 Tahun 2008

tentang Perbankan Syariah

Wibowo, Edy \& Untung Hendy Widodo.

2005. Mengapa Memilih Bank

Syariah?. Bogor: Ghalia Indonesia

Wiroso. 2009. Produk Perbankan Syariah. Jakarta: LPFE Usakti.

Yin, Robert. 2002. Studi Kasus Desain dan Metode.Jakarta: PT Raja Grafndo Persada

Undang-undang No. 21 Tahun 2008 tentang Perbankan Syariah

http://www.bi.go.id/web/id/perbankan/p erbankan+syariah

http://www.bnisyariah.co.id/investor/lapor an+kevangan 